This item was submitted to Loughborough's Research Repository by the author.

Items in Figshare are protected by copyright, with all rights reserved, unless otherwise indicated.

\title{
Regime Shifts in European Real Interest Rates
}

PLEASE CITE THE PUBLISHED VERSION

PUBLISHER

(c) Loughborough University

LICENCE

CC BY-NC-ND 4.0

REPOSITORY RECORD

Mills, Terence C., and Ping Wang. 2019. "Regime Shifts in European Real Interest Rates". figshare. https://hdl.handle.net/2134/728. 
This item was submitted to Loughborough's Institutional Repository by the author and is made available under the following Creative Commons Licence conditions.

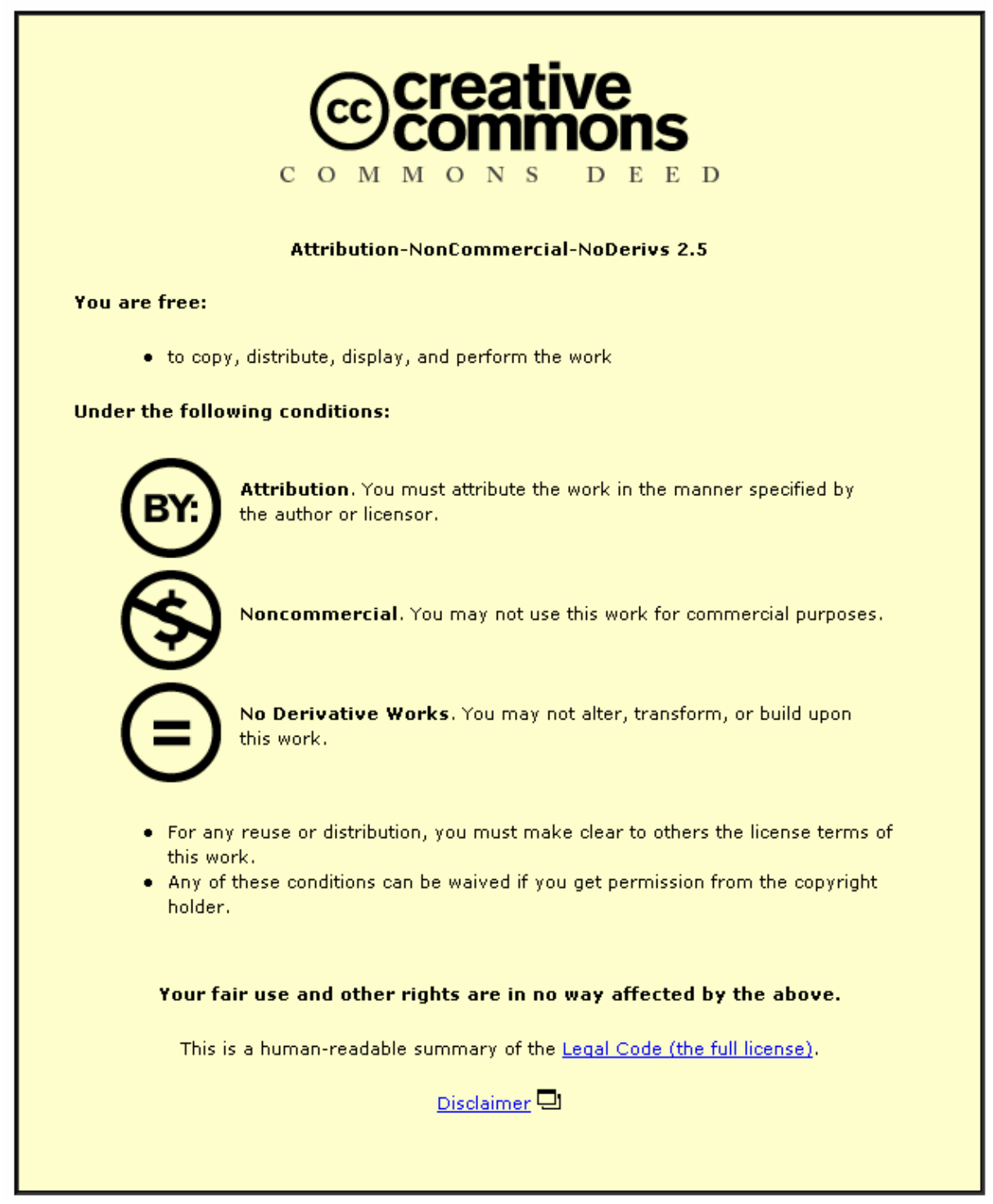

For the full text of this licence, please go to: http://creativecommons.org/licenses/by-nc-nd/2.5/ 


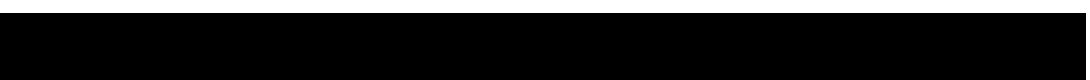

Department of Economics

Business Cycle Volatility and Economic Growth Research Paper No. 01/5

REgIME SHIFTS IN EUROPEAN REAL

INTEREST RATES

Terence C. Mills and Ping Wang

November 2001

This paper forms part of the ESRC funded project (Award No. L1382511013) "Business Cycle Volatility and Economic Growth: A Comparative Time Series Study", which itself is part of the Understanding the Evolving Macroeconomy Research programme. 


\section{Introduction}

The nonstationarity of the real interest rate has long been an important issue, both for monetary and fiscal policy and for financial theory. West (1988), for example, shows that an interest rate smoothing monetary policy leads to nonstationarity in the real interest rate in the context of an overlapping wage-contract model, while DeLong and Summers (1986) show that a similar effect is produced by nonstationary shocks to aggregate demand. Such nonstationarity is also inconsistent with the Black-Scholes option pricing assumption of a constant ex-ante real rate, and it would also lead to a rejection of the consumption-based CAPM (Rose, 1988). While Fama (1975) provided evidence that the U.S. ex-ante real interest rate was constant in his influential study of the efficiency of the Treasury bill market, this has since been shown to be almost certainly due to his choice of a 1953 to 1971 sample period. Indeed, most subsequent research has found against a constant real interest rate in favour of nonstationarity (see, for example, Rose, 1988).

The form of this nonstationarity has typically been assumed to be of a random walk nature. More recently, Perron (1990) and Garcia and Perron (1996) have considered models in which nonstationarity of the ex-post real interest rate is a consequence of infrequent changes in the mean and variance. The latter adopt a variant of Hamilton's (1989) Markov switching model to explicitly account for regime shifts in an autoregressive model of the ex-post real interest rate. Using the 90 day Treasury bill rate for the nominal interest rate and a quarterly inflation rate constructed from the CPI, they show that the ex-post U.S. real interest rate is essentially constant but with means that are different for the periods 1961-1973, 19731981 and 1981-1986. The dates of the shifts are in line with the sudden jump in oil prices in 1973 and with the rise of the federal budget deficit in the beginning of the 1980s. These shifts in the real interest rate are argued to be the reason why the presence of a random walk component cannot be rejected using conventional tests for a unit root. Garcia and Perron's (1996) results thus support Fama's original view of a constant real interest rate, but with the crucial difference that the mean of the series is subject to occasional shifts, implying that shocks are generally temporary but that the real interest rate is subject to infrequent permanent shocks that produce regime shifts.

As Garcia and Perron (1996) only focus on the U.S. for the quarter of a century from the beginning of the 1960s to the middle of the 1980s, whether their finding is unique to that particular period of the U.S. or is universally valid is an important issue. We thus extend their analysis to four major European economies, using data through the 1990s decade of low inflation and interest rates, and present cross-country comparisons. The paper proceeds as follows. Section 2 outlines the 
regime switching model that we employ, while section 3 discusses the results of estimating the model on our four series and the issues involved in model selection. Section 4 offers an alternative, descriptive, method of analysing the data to assess the sensitivity and robustness of the results obtained in section 3. Using the selected models, ex-ante real interest rates are calculated in section 5 and their behaviour across time and countries is compared and contrasted. Section 6 concludes and relates our findings for Europe with those already obtained for the U.S.

\section{Model Specification and Estimation}

We denote the ex-post real interest rate as $y_{t}=r_{t}-\pi_{t}$, where $r_{t}$ is the rate of interest observed at time $t$ and $\pi_{t}=\log \left(P_{t+1} / P_{t}\right)$ is the ex-post rate of inflation calculated from the price index $P_{t}$. Both $y_{t}$ and $r_{t}$ are observed quarterly and measured as annualised rates. Following Garcia and Perron (1996), we assume that $y_{t}$ is generated as an autoregression of order $p$ with regime switching mean and variance

$$
y_{t}-\mu\left(S_{t}\right)=\sum_{i=1}^{p} \phi_{i}\left(y_{t-i}-\mu\left(S_{t-i}\right)\right)+\sigma\left(S_{t}\right) \varepsilon_{t}
$$

Here the mean $\mu$ and the standard deviation $\sigma$ of the process depend on the regime at time $t$, indexed by $S_{t}$, a discrete variable, and $\varepsilon_{t}$ is an i.i.d. $N(0,1)$ random variable. $S_{t}$ is assumed to be an $n$-state, first order Markov process, taking the values $1, \mathrm{~K}, n$ with transition probability matrix

$$
P=\left\langle P_{i j}\right\rangle, \quad i, j=1, \mathrm{~K}, n
$$

where $P_{i j}=\operatorname{Pr}\left[S_{t}=j \mid S_{t-1}=i\right]$ with $\sum_{j=1}^{n} P_{i j}=1$ for all $i$.

The state dependent means and variances are specified as

$$
\begin{aligned}
& \mu\left(S_{t}\right)=\mu_{1} S_{1 t}+\mathrm{K}+\mu_{n} S_{n, t} \\
& \sigma^{2}\left(S_{t}\right)=\sigma_{1}^{2} S_{1 t}+\mathrm{K}+\sigma_{n}^{2} S_{n, t}
\end{aligned}
$$

where $S_{i t}$ takes the value 1 when $S_{t}$ is equal to $i$ and 0 otherwise. Equation (1) can then be written as

$$
\begin{aligned}
& y_{t}=\mu_{1} S_{1 t}+\mathrm{K}+\mu_{n} S_{n, t}+z_{t} \\
& z_{t}=\sum_{i=1}^{p} \phi_{i} z_{t-i}+\left(\sigma_{1}^{2} S_{1 t}+\mathrm{K}+\sigma_{n}^{2} S_{n, t}\right)^{1 / 2} \varepsilon_{t}
\end{aligned}
$$


Conditional on knowing $S_{t}, t=1, \mathrm{~K}, T$, the joint conditional log-likelihood function of $y_{t}$ is

$$
L\left(y_{n}, \mathrm{~K}, y_{T}\right)=-\frac{T}{2} \log 2 \pi-\sum_{t=n}^{T}\left(\log \sigma\left(S_{t}\right)+\frac{v_{t}^{2}}{2 \sigma\left(S_{t}\right)^{2}}\right)
$$

where

$$
v_{t}=z_{t}-\sum_{i=1}^{p} \phi_{1} z_{t-i}=\sigma\left(S_{t}\right) \varepsilon_{t}
$$

Since $S_{t}$ is unobservable, the unknown parameters of the model can be estimated using the non-linear filter proposed by Hamilton (1989), which is based on the loglikelihood

$$
L\left(y_{n}, \mathrm{~K}, y_{T}\right)=\sum_{t=n}^{T} L\left(y_{t} \mid y_{t-1}, y_{t-2}, \mathrm{~K}, y_{1}\right)
$$

Hamilton's algorithm obtains, as a by-product, the sequence of joint conditional probabilities $\operatorname{Pr}\left(S_{t}, S_{t-1}, \mathrm{~K}, S_{t-n} \mid y_{t}, \mathrm{~K}, y_{1}\right)$, which are the probabilities that $y_{t}$ is in state $1, \mathrm{~K}, n$ at times $t, t-1, \mathrm{~K}, t-n$, respectively, conditional upon the information available at time $t$. By summing these joint probabilities, we can obtain the filter probabilities - the probabilities of being in state $1, \mathrm{~K}, n$ at time These provide information about the state in which $y_{t}$ is most likely to be at every point in the sample.

\section{Empirical Results and Model Selection}

We analyse the real interest rates for the four European countries, the U.K., France, Italy and Germany. The real interest rate for each country is constructed using the CPI as the price index in the inflation calculation and the three-month Treasury bill rate as the nominal interest rate. All of the data come from Datastream, which in turn takes the data from different sources. ${ }^{1}$ The sample periods used for

1960:1 - 1999:4; Germany, 1965:1 - 2001:2. (Augmented) Dickey Fuller unit root -2.75 for the U.K, -1.77 for France, -2.18 for Italy and -4.02 for Germany. With a $5 \%$ critical value of approximately -2.88 , we can see that a unit root in the real interest rates for

\footnotetext{
${ }^{1}$ While all the CPI series are from the IMF database, the nominal interest rates are from different sources. For Italy, it is the 3-month deposit rate from OECD (ITOCTBL\%); for France it is the 3month Treasure bill rate from IMF (FRI60C.), for Germany it is the 3-month FIBOR (BDINTER3) and for the U.K. it is again the 3-month Treasury bill rate from Economic Trends. These choices were based on the longest availability of data.
} 
both France and Italy cannot be rejected, the evidence is less clear-cut for the U.K., but a unit root can clearly be rejected for Germany.

The estimates of one, two and three-state Markov switching models ( $n=1,2,3)$ for each country are presented in Tables 1 to 4 . For $n=1$, i.e., a constant mean and variance specification, the autoregressive lag order was set at $p=4$, while for higher orders of $n$, models with lags $p=2$ and $p=4$ were estimated. This was because there is evidence that choosing too low a number of states may lead to a spuriously high lag order (see the discussion in Garcia and Perron, 1996). However, the identification of the number of regimes in Markov switching models cannot be done through usual likelihood ratio, Lagrange multiplier, or Wald tests since their asymptotic distributions are non-standard. To overcome this problem, Garcia and Perron (1996) use a number of tests to guide them in their decision making. Here we adopt the Davies (1987) upper bound test in conjunction with the estimated parameters and the filtered probabilities. The Davies upper bound is based on an adjustment to the LR test statistic, and provides an upper bound for the correct probability value. Details of this test are presented in Appendix A of Garcia and Perron (1996). Let $L_{1}$ be the log-likelihood under the alternative and $L_{0}$ be the loglikelihood under the null, where $q$ parameters are present only under the alternative, and define the standard likelihood ratio test as $M=2\left(L_{1}-L_{0}\right)$. Then, on the assumption that the likelihood ratio has a single peak, an upper bound for the significance of $M$ is given by

$$
\operatorname{Pr}\left[\chi_{q}^{2}>M\right]+2(M / 2)^{q / 2} \exp (-M / 2) / \Gamma(q / 2)
$$

where $\Gamma($.$) denotes the gamma function. Since this upper bound must be greater than$ $\operatorname{Pr}\left\lfloor\chi_{q}^{2}>M\right\rfloor$, the usual marginal probability associated with the likelihood ratio test, non-rejection of the null using this marginal probability can only be confirmed by the Davies upper bound. Only when a rejection of the null is signalled by the conventional test does the upper bound need to be calculated. As the tables show, for a given lag order, testing the null of $n-1$ states against $n(n>1)$ implies $q=2$. From (2), it can be calculated that an upper bound of 0.05 requires a value of $M$ of 10.95 , rather than the conventional $\chi_{2}^{2}$ value of 5.99. Similarly, testing $n=1$ against $n=3$ implies $q=4$ and a $5 \%$ upper bound critical value of 15.75 . Values of $M$ above these upper bounds would thus suggest rejecting the particular null hypothesis being tested. Testing of the lag order conditional upon a particular value of $n$ can be carried out using conventional $\chi^{2}$ critical values.

Using these ideas, the log-likelihoods for the U.K. shown in table 1 strongly point towards either the $(n=2, p=4)$ or the $(n=3, p=4)$ models, as the one-state 
model is clearly inferior to either the two- or three-state models and a lag order of two is inferior to one of four. For the two-state model, the means of the states are $-4.5 \%$ and $2.2 \%$ with variances 56.6 and 8.5 respectively. The three-state model has means of $-2.7 \%, 0.8 \%$ and $4.1 \%$, with variances of 59.2, 9.4 and 6.6 . The two-state model thus appears to 'average' out the second and third states in the more general model. This would be appropriate if, in the three-state model, $\mu_{2}=\mu_{3}$ and $\sigma_{2}^{2}=\sigma_{3}^{2}$. While the latter hypothesis cannot be rejected (the test statistic is $\chi_{1}^{2}=2.61$ ), the former hypothesis most certainly can $\left(\chi_{1}^{2}=8.09\right)$. We thus select the three-state model, for which the filtered probabilities of the real rate being in each of the three states at any time are shown in figure 1(a). The 'low' state of negative real rates occurs in two short bursts - during 1975 and again during 1980 and 1981. The 'medium' state of just positive real rates exists for the period up to 1975 and between 1977 and 1979, while the 'high' state occurs briefly during 1976 and then from 1982 onwards.

For France, whose results are shown in table 2, lag orders of four are preferred to orders of two, but the $M$ statistics cannot statistically distinguish between the one-, two- or three-state models. However, for the $n=3$ model, state 1 yields $\mu_{1}=-7.08 \%$ and $\sigma_{1}^{2}=49.7$, with the latter having an associated standard error of 79.3. Examination of the plot of the observed real rate for France (see Figure 2(b)) shows that the minimum value is only $-5.33 \%$, so that this first state looks to be spurious. Figure 1(b) shows the filtered probabilities from the two-state model and these look to separate out the data adequately. Up to 1982 the real rate was in a 'low' state with a mean of approximately $-1 \%$, after this date it was in a 'high' state with a mean of approximately 5\%. The volatility in both states is rather modest and quite similar in magnitude.

For Italy, the results of table 3 again strongly point towards either the $(n=2, p=4)$ or the $(n=3, p=4)$ models, as the one-state model is clearly inferior to either the two- or three-state models and a lag order of two is inferior to one of four. The two-state model implies a highly volatile 'low' state centered on $-4.5 \%$ and a less volatile 'high' state centered on $2 \%$. The three-state model has a high volatility 'low' state centered on $0.2 \%$, and low volatility 'medium' and 'high' states centered on $1.3 \%$ and $5.6 \%$, respectively. This latter model provides, we feel, a better description of the series and an interpretable separation of the data as shown by the filtered probabilities in figure 1(c). The low state is in operation before 1965 and between 1972 and 1985, the medium state holds between 1965 and 1972, and the high state holds sway after 1985.

For Germany, the results of table 4 show that the $(n=3, p=4)$ model is selected. The three states have estimated means of $0.8 \%, 2.4 \%$ and $4 \%$, with variances 4.2, 0.6 and 8.1 respectively. As can be seen from figure $1(\mathrm{~d})$, the real rate 
does not stay in any state for a prolonged period, which is reflected by the relative small transition probabilities. While the constant mean $(n=1)$ model is clearly rejected, the behaviour of this series is markedly different from the others. The frequent regime shifts seen in these plots are consistent with the rejection of unit root non-stationarity in favour of constant mean stationarity.

\section{Supporting Evidence from Nonparametric Modelling}

The analysis has so far been conducted within a tightly specified probability model that assumes that nonstationarity is produced by occasional shifts in the mean and variance of a process that otherwise is characterised by means and variances that are constant. This, of course, is at odds with the evidence of unit root nonstationarity provided by the Dickey-Fuller tests for three of the countries, Germany being the exception. Although the power to detect departures from a unit root null in the direction of occasional shifts in an otherwise stationary environment is almost certainly rather low, we feel that it is important to examine the robustness of our results by employing alternative techniques that do not require such a formal modelling framework. The descriptive econometric techniques for possibly nonstationary time series recently developed by Phillips (2001a, 2001b) provide a convenient vehicle for doing just that.

Phillips shows that a rescaling of the usual kernel estimate of the probability density of (an assumed stationary) $y_{t}$ :

$$
\hat{f}_{T}(y)=\left(T h_{T}\right)^{-1} \sum_{t=1}^{T} K\left(\frac{\left(y-y_{t}\right)}{h_{T}}\right)
$$

where $h_{T}$ is the bandwidth parameter and $K(\cdot)$ is a symmetric, nonnegative kernel function that integrates to unity, still has meaning even when $y_{t}$ is nonstationary through containing a unit root. The rescaling $\hat{S}(y / \sqrt{T})=\sqrt{T} \hat{f}_{T}(y)$ tells us how dense the process is about a particular spatial point, and can thus be interpreted as a 'spatial density'. The quantity $\hat{S}\left(y^{0} / \sqrt{T}\right)$ is thus an estimate of the proportion of time that the standardised series $y / \sqrt{T}$ spends in the vicinity of $y^{0} / \sqrt{T}$, and is referred to by Phillips as the 'sojourn time'.

Following Phillips (2001a), we use a normal kernel for $K(\cdot)$ and set the bandwidth parameter as $h_{T}=T^{-1 / 5}$. The spatial densities for each of the ex-post real interest rate series are shown as figures 2(a)-(d). Superimposed on each of the densities are shaded areas representing one standard error bands around the estimated state means from tables 1 to 4 . For the U.K., the two highest peaks of the spatial 
density shown in panel (a) correspond well with the positive states 2 and 3. State 1 looks to be an average of the two minor negative peaks in the spatial density, but nevertheless the spatial density corresponds well with the selected three-state model. A two-state model was selected for France, but both the one- and three-state models were close in terms of goodness of fit. For the two-state model, the positive state 2 in panel (b) corresponds well with the peak of the spatial density, but the negative state, whose mean is estimated at $-1 \%$, is not captured particularly well by the spatial density. If a three state model had been selected, with means of $-7.1 \%, 0.6 \%$ and $5.7 \%$, then the second and third states correspond well with the spatial density, but the first is confirmed to be completely spurious. The one-state model has a single mean estimated as $0.3 \%$. This is also shown in panel (b) and corresponds to the local peak, but the model necessarily misses the global peak completely. Although by no means a perfect match, the spatial density seems to confirm that the two-state model is probably the most appropriate.

For Italy, a three-state model was chosen over a two-state. The spatial density shown in panel (c) exhibits two peaks, but these are not near the estimated means of the two-state model, $-4.5 \%$ and $2 \%$. States 1 and 2 of the three-state model encompass the peak of the spatial density and state 3 is close to the secondary peak, which suggests that the choice made above is again appropriate. Panel (d) shows the spatial density for Germany. States 1 and 3 of the selected three-state model pick out the two major peaks, although state 2 is identified with the upslope of the global peak. The third peak, at around $-1.5 \%$, is never identified in any of the models reported in Table 4. Again, the spatial density is consistent with our choice of a three-state model.

The spatial densities also provide some indirect evidence concerning the nonstationarity of the ex-post real interest rates. Phillips (2001a) provides simulation evidence to show that, if a series is generated by a unit root process, then its spatial density will contain many local peaks with no dominant peak. Panels (a) to (c) clearly show a limited number of peaks, with one dominant, and this confirms that the nonstationarity in these real rates is unlikely to be produced by an underlying unit root process. The spatial density for Germany is much smoother and is more like that obtained by Phillips for a stationary autoregressive process. This is therefore consistent with the rejection of a unit root by the Dickey-Fuller test, although we find that a model with occasional shifts in mean and variance fits the series better. 


\section{Estimating Ex-Ante Real Interest Rates}

Using the models selected in section 3 and confirmed by the supporting analysis of section 4, we also estimated the ex-ante real interest rate for each of the four countries. As suggested by Garcia and Perron (1996), these were calculated using

$$
y_{t}^{e a}=\sum_{j=1}^{n} \mu_{j}\left(\sum_{i=1}^{n} P_{i j} \operatorname{Pr}\left[S_{t}=i \mid y_{t}, y_{t-1}, \mathrm{~K}, y_{1}\right]\right)
$$

so that they are averages of the state means weighted by the conditional probabilities of being in each state at time $t$. The ex-ante real rates for the U.K., France and Italy, shown in figures 3(a)-3(d) along with the much more volatile ex-post rates, display similar patterns, although there are timing differences. All three exhibit two long stretches of stable rates, the second period being characterised by higher rates than the first, interspersed by a period of volatility. This volatile period covers the years 1974 to 1982 for the U.K., 1982 to 1984 for France, and 1977 to 1984 for Italy. The behaviour of the ex-ante real rate for Germany is markedly different, however. As remarked on above, no state dominates for any substantial period, so that the rate appears to fluctuate around $23 / 4 \%$. For all four countries, the ex-ante rate diverges markedly from the ex-post rate, and this divergence is persistent, which reflects the finding that autoregressions of order four are required to model the noise process in each ex-post rate.

The behaviour of the ex-ante real interest rate for the U.K. accords well with the view that interest rates and inflation were fairly stable up to the first oil shock in 1973 , with the rate fluctuating around a value of $3 / 4 \%$. The economy then went through almost a decade of dislocation and volatility, before the ex-ante real rate settled onto a higher state of approximately $33 / 4 \%$. France's ex-ante real rate was unaffected by the oil shocks of the 1970 s, remaining at around $-0.8 \%$, presumably because a policy of inflation accommodation was pursued. Subsequently, France went through a series of exchange rate crises between 1981 and 1983, which resulted in a policy shift toward controlling inflation, and which led to the rate moving to a higher state of around $4.7 \%$. Italy too had a long period of stable ex-ante real rates (around 1\%), brought about by a combination of low inflation and artificially low nominal interest rates. The economic and, in particular, political shocks of the 1970s had profound impacts on the Italian economy and it was not until 1984 that a new stable regime emerged, with ex-ante real rates fluctuating around a much higher level of 5.3\%. As stated above, Germany's ex-ante real interest rate evolution is in stark contrast to these three cases, fluctuating throughout the period between 1965 and 
2000 in the relatively narrow range of $2 \%$ to $3.5 \%$. Even the reunification in 1990 had only a transitory effect on ex-post real rates and little effect on the ex-ante rate.

\section{Conclusions}

The presence of a random walk component in the real interest rate is an important issue for both economic policy and theory. If the real interest rate does not contain a random walk, then shocks to it are temporary in nature and there is a tendency for it to revert to some average value. Garcia and Perron (1996), using data from 1961 to 1986, found that the average value of the U.S real interest rate was subject to occasional jumps caused by external shocks, but between these shocks the average was essentially constant. They identified two such shocks: the sudden rise in the price of oil in 1973 and an upward jump in 1981, which they attributed to a shift in the federal budget deficit. Garcia and Perron thus concluded that the evidence favoured the constancy of the ex-ante real rate over reasonably lengthy periods of time.

We have extended their analysis by investigating whether such a conclusion holds for four major European economies over a sample period that includes the 1990 s, a period of generally stable and low inflation and nominal interest rates. For each of the countries, evidence was found in favour of a small number of regime shifts, apart from which the average level of the real rate remained stable. Like the U.S., both the U.K. and Italy underwent shifts in the mid-1970s, when for several years the ex-ante real rate was volatile. After this period of volatility, rates in both countries have remained stable throughout the 1980 and 1990s. A similar pattern has occurred for France, although here the period of volatility was both delayed and shortened. The behaviour of the ex-ante real rate in Germany is noticeably different, fluctuating in a rather narrow positive band throughout the last four decades of the $20^{\text {th }}$ century, hardly being affected by oil price shocks and, indeed, reunification.

We thus conclude that, like the U.S., European real interest rates have generally been stable, only shifting in response to occasional external shocks. This evidence therefore provides further support for Fama's (1975) original contention that, for many purposes, the ex-ante real interest rate can be regarded, to a first approximation, as a constant. 


\section{References}

Davies, R.B. (1987), 'Hypothesis testing when a nuisance parameter is present only under the alternative', Biometrika, 74, 33-43.

DeLong, J.B. and Summers, L.H. (1986), 'Is increased price flexibility stabilizing?', American Economic Review, 76, 1031-1044.

Fama, E.F. (1975), 'Short-term interest rates as predictors of inflation', American Economic Review, 65, 269-282.

Garcia, R. and Perron, P. (1996), 'An analysis of the real interest rate under regime shifts', Review of Economics and Statistics, 78, 111-125.

Hamilton, J.D. (1989), 'A new approach to the economic analysis of nonstationary time series and the business cycle', Econometrica, 57, 357-384.

Perron, P. (1990), 'Testing for a unit root in a time series with a changing mean', Journal of Business and Economic Statistics, 8, 153-162.

Phillips, P.C.B. (2001a), 'Descriptive econometrics for nonstationary time series with empirical illustrations', Journal of Applied Econometrics, 16, 389-413.

Phillips, P.C.B. (2001b), 'Econometric analysis of Fisher's equation', in J. Geanakoplos and W.C. Brainard (editors), Essays in Memory of Irving Fisher, Cambridge University Press.

Rose, A.K. (1988), 'Is the real interest rate stable?', Journal of Finance, 43, 10951112 .

West, K.D. (1988), 'On the interpretation of near random walk behaviour in GNP', American Economic Review, 78, 202-209. 
Table 1: Model estimates for the U.K. The entries in the row labelled $M$ are, respectively: (col. 1) Likelihood ratio (LR) test of $n=1$ against $n=2$ conditional on $p=4$; (col. 2) LR test of $p=2$ against $p=4$ conditional on $n=2$; (col. 3) LR test of $n=2$ against $n=3$ conditional on $p=4$; (col. 4) LR test of $p=2$ against $p=4$ conditional on $n=3$; (col. 5) LR test of $n=1$ against $n=3$ conditional on $p=4$. The entries in the row labelled $M_{c}$ are the corresponding $5 \%$ critical values.

\begin{tabular}{|c|c|c|c|c|c|}
\hline & $\begin{array}{l}n=1 \\
p=4\end{array}$ & $\begin{array}{l}n=2 \\
p=2\end{array}$ & $\begin{array}{l}n=2 \\
p=4\end{array}$ & $\begin{array}{l}n=3 \\
p=2\end{array}$ & $\begin{array}{l}n=3 \\
p=4\end{array}$ \\
\hline$p_{11}$ & & $\begin{array}{l}0.993 \\
(0.007)\end{array}$ & $\begin{array}{l}0.984 \\
(0.012)\end{array}$ & $\begin{array}{l}0.966 \\
(0.031)\end{array}$ & $\begin{array}{l}0.860 \\
(0.094)\end{array}$ \\
\hline$p_{12}$ & & & & $\begin{array}{l}0.000 \\
(0.000)\end{array}$ & $\begin{array}{l}0.000 \\
(0.000)\end{array}$ \\
\hline$p_{21}$ & & & & $\begin{array}{l}0.006 \\
(0.007)\end{array}$ & $\begin{array}{l}0.023 \\
(0.018)\end{array}$ \\
\hline$p_{22}$ & & $\begin{array}{l}0.961 \\
(0.040)\end{array}$ & $\begin{array}{l}0.823 \\
(0.119)\end{array}$ & $\begin{array}{l}0.994 \\
(0.007)\end{array}$ & $\begin{array}{l}0.977 \\
(0.018)\end{array}$ \\
\hline$p_{31}$ & & & & $\begin{array}{l}0.000 \\
(0.000)\end{array}$ & $\begin{array}{l}0.000 \\
(0.000)\end{array}$ \\
\hline$p_{32}$ & & & & $\begin{array}{l}0.006 \\
(0.008)\end{array}$ & $\begin{array}{l}0.022 \\
(0.019)\end{array}$ \\
\hline$\phi_{1}$ & $\begin{array}{l}0.236 \\
(0.043)\end{array}$ & $\begin{array}{l}0.190 \\
(0.077)\end{array}$ & $\begin{array}{l}0.130 \\
(0.063)\end{array}$ & $\begin{array}{l}0.055 \\
(0.076)\end{array}$ & $\begin{array}{l}0.074 \\
(0.066)\end{array}$ \\
\hline$\phi_{2}$ & $\begin{array}{l}0.146 \\
(0.051)\end{array}$ & $\begin{array}{l}0.280 \\
(0.080)\end{array}$ & $\begin{array}{l}0.152 \\
(0.058)\end{array}$ & $\begin{array}{l}0.147 \\
(0.075)\end{array}$ & $\begin{array}{l}0.127 \\
(0.058)\end{array}$ \\
\hline$\phi_{3}$ & $\begin{array}{l}-0.045 \\
(0.049)\end{array}$ & & $\begin{array}{l}-0.004 \\
(0.050)\end{array}$ & & $\begin{array}{l}-0.028 \\
(0.062)\end{array}$ \\
\hline$\phi_{4}$ & $\begin{array}{l}0.457 \\
(0.036)\end{array}$ & & $\begin{array}{l}0.487 \\
(0.060)\end{array}$ & & $\begin{array}{l}0.470 \\
(0.059)\end{array}$ \\
\hline$\sigma_{1}^{2}$ & $\begin{array}{l}14.22 \\
(1.56)\end{array}$ & $\begin{array}{l}40.42 \\
(14.02)\end{array}$ & $\begin{array}{l}56.58 \\
(20.50)\end{array}$ & $\begin{array}{l}39.70 \\
(11.48)\end{array}$ & $\begin{array}{l}59.19 \\
(21.64)\end{array}$ \\
\hline$\sigma_{2}^{2}$ & & $\begin{array}{l}11.63 \\
(1.35)\end{array}$ & $\begin{array}{l}8.48 \\
(1.02)\end{array}$ & $\begin{array}{l}10.13 \\
(1.59)\end{array}$ & $\begin{array}{l}9.36 \\
(1.50)\end{array}$ \\
\hline$\sigma_{3}^{2}$ & & & & $\begin{array}{l}10.78 \\
(1.88)\end{array}$ & $\begin{array}{l}6.58 \\
(1.32)\end{array}$ \\
\hline$\mu_{1}$ & $\begin{array}{l}0.412 \\
(0.265)\end{array}$ & $\begin{array}{l}-3.155 \\
(2.049)\end{array}$ & $\begin{array}{l}-4.548 \\
(2.246)\end{array}$ & $\begin{array}{l}-3.597 \\
(1.527)\end{array}$ & $\begin{array}{l}-2.660 \\
(2.075)\end{array}$ \\
\hline$\mu_{2}$ & & $\begin{array}{l}2.722 \\
(0.605)\end{array}$ & $\begin{array}{l}2.175 \\
(0.961)\end{array}$ & $\begin{array}{l}0.908 \\
(0.484)\end{array}$ & $\begin{array}{l}0.812 \\
(0.868)\end{array}$ \\
\hline$\mu_{3}$ & & & & $\begin{array}{l}4.576 \\
(0.46)\end{array}$ & $\begin{array}{l}4.084 \\
(0.84)\end{array}$ \\
\hline$L$ & -530.01 & -544.00 & -509.36 & -534.40 & -508.10 \\
\hline$M$ & 41.30 & 69.27 & 2.53 & 52.59 & 43.83 \\
\hline$M_{c}$ & 10.95 & 5.99 & 10.95 & 5.99 & 15.75 \\
\hline
\end{tabular}


Table 2: Model estimates for France. The entries in the row labelled $M$ are, respectively: (col. 1) Likelihood ratio (LR) test of $n=1$ against $n=2$ conditional on $p=4$; (col. 2) LR test of $p=2$ against $p=4$ conditional on $n=2$; (col. 3) LR test of $n=2$ against $n=3$ conditional on $p=4$; (col. 4) LR test of $p=2$ against $p=4$ conditional on $n=3$; (col. 5) LR test of $n=1$ against $n=3$ conditional on $p=4$. The entries in the row labelled $M_{c}$ are the corresponding $5 \%$ critical values.

\begin{tabular}{|c|c|c|c|c|c|}
\hline & $\begin{array}{l}n=1 \\
p=4\end{array}$ & $\begin{array}{l}n=2 \\
p=2\end{array}$ & $\begin{array}{l}n=2 \\
p=4\end{array}$ & $\begin{array}{l}n=3 \\
p=2\end{array}$ & $\begin{array}{l}n=3 \\
p=4\end{array}$ \\
\hline$p_{11}$ & & $\begin{array}{l}0.982 \\
(0.016)\end{array}$ & $\begin{array}{l}0.985 \\
(0.016)\end{array}$ & $\begin{array}{l}0.000 \\
(0.000)\end{array}$ & $\begin{array}{l}0.000 \\
(0.001)\end{array}$ \\
\hline$p_{12}$ & & & & $\begin{array}{l}0.000 \\
(0.000)\end{array}$ & $\begin{array}{l}0.000 \\
(0.000)\end{array}$ \\
\hline$p_{21}$ & & & & $\begin{array}{l}0.011 \\
(0.011)\end{array}$ & $\begin{array}{l}0.011 \\
(0.011)\end{array}$ \\
\hline$p_{22}$ & & $\begin{array}{l}0.987 \\
(0.015)\end{array}$ & $\begin{array}{l}0.987 \\
(0.015)\end{array}$ & $\begin{array}{l}0.989 \\
(0.011)\end{array}$ & $\begin{array}{l}0.989 \\
(0.011)\end{array}$ \\
\hline$p_{31}$ & & & & $\begin{array}{l}0.000 \\
(0.000)\end{array}$ & $\begin{array}{l}0.000 \\
(0.000)\end{array}$ \\
\hline$p_{32}$ & & & & $\begin{array}{l}0.024 \\
(0.020)\end{array}$ & $\begin{array}{l}0.024 \\
(0.020)\end{array}$ \\
\hline$\phi_{1}$ & $\begin{array}{l}0.548 \\
(0.043)\end{array}$ & $\begin{array}{l}0.589 \\
(0.095)\end{array}$ & $\begin{array}{l}0.573 \\
(0.101)\end{array}$ & $\begin{array}{l}0.626 \\
(0.091)\end{array}$ & $\begin{array}{l}0.609 \\
(0.094)\end{array}$ \\
\hline$\phi_{2}$ & $\begin{array}{l}0.108 \\
(0.040)\end{array}$ & $\begin{array}{l}0.097 \\
(0.093)\end{array}$ & $\begin{array}{l}0.094 \\
(0.107)\end{array}$ & $\begin{array}{l}-0.101 \\
(0.089)\end{array}$ & $\begin{array}{l}-0.031 \\
(0.105)\end{array}$ \\
\hline$\phi_{3}$ & $\begin{array}{l}0.022 \\
(0.042)\end{array}$ & & $\begin{array}{l}-0.066 \\
(0.106)\end{array}$ & & $\begin{array}{l}-0.118 \\
(0.100)\end{array}$ \\
\hline$\phi_{4}$ & $\begin{array}{l}0.218 \\
(0.046)\end{array}$ & & $\begin{array}{l}0.125 \\
(0.098)\end{array}$ & & $\begin{array}{l}0.027 \\
(0.090)\end{array}$ \\
\hline$\sigma_{1}^{2}$ & $\begin{array}{l}3.73 \\
(0.48)\end{array}$ & $\begin{array}{l}4.36 \\
(0.93)\end{array}$ & $\begin{array}{l}4.36 \\
(0.96)\end{array}$ & $\begin{array}{l}42.37 \\
(67.66)\end{array}$ & $\begin{array}{l}49.74 \\
(79.27)\end{array}$ \\
\hline$\sigma_{2}^{2}$ & & $\begin{array}{l}2.35 \\
(0.42)\end{array}$ & $\begin{array}{l}2.42 \\
(0.46)\end{array}$ & $\begin{array}{l}4.24 \\
(0.75)\end{array}$ & $\begin{array}{l}4.31 \\
(0.77)\end{array}$ \\
\hline$\sigma_{3}^{2}$ & & & & $\begin{array}{l}1.67 \\
(0.35)\end{array}$ & $\begin{array}{l}1.62 \\
(0.35)\end{array}$ \\
\hline$\mu_{1}$ & $\begin{array}{l}0.282 \\
(0.175)\end{array}$ & $\begin{array}{l}-0.866 \\
(1.021)\end{array}$ & $\begin{array}{l}-1.000 \\
(1.111)\end{array}$ & $\begin{array}{l}-6.400 \\
(2.404)\end{array}$ & $\begin{array}{l}-7.081 \\
(2.511)\end{array}$ \\
\hline$\mu_{2}$ & & $\begin{array}{l}5.032 \\
(0.571)\end{array}$ & $\begin{array}{l}4.865 \\
(0.663)\end{array}$ & $\begin{array}{l}0.635 \\
(0.526)\end{array}$ & $\begin{array}{l}0.598 \\
(0.507)\end{array}$ \\
\hline$\mu_{3}$ & & & & $\begin{array}{l}5.654 \\
(0.397)\end{array}$ & $\begin{array}{l}5.701 \\
(0.384)\end{array}$ \\
\hline$L$ & -251.33 & -251.44 & -246.87 & -248.46 & -244.13 \\
\hline$M$ & 8.92 & 9.15 & 5.48 & 8.67 & 14.40 \\
\hline$M_{c}$ & 10.95 & 5.99 & 10.95 & 5.99 & 15.75 \\
\hline
\end{tabular}


Table 3: Model estimates for Italy. The entries in the row labelled $M$ are, respectively: (col. 1) Likelihood ratio (LR) test of $n=1$ against $n=2$ conditional on $p=4$; (col. 2) LR test of $p=2$ against $p=4$ conditional on $n=2$; (col. 3) LR test of $n=2$ against $n=3$ conditional on $p=4$; (col. 4) LR test of $p=2$ against $p=4$ conditional on $n=3$; (col. 5) LR test of $n=1$ against $n=3$ conditional on $p=4$. The entries in the row labelled $M_{c}$ are the corresponding $5 \%$ critical values.

\begin{tabular}{|c|c|c|c|c|c|}
\hline & $\begin{array}{l}n=1 \\
p=4\end{array}$ & $\begin{array}{l}n=2 \\
p=2\end{array}$ & $\begin{array}{l}n=2 \\
p=4\end{array}$ & $\begin{array}{l}n=3 \\
p=2\end{array}$ & $\begin{array}{l}n=3 \\
p=4\end{array}$ \\
\hline$p_{11}$ & & $\begin{array}{l}0.992 \\
(0.010)\end{array}$ & $\begin{array}{l}0.880 \\
(0.065)\end{array}$ & $\begin{array}{l}0.963 \\
(0.030)\end{array}$ & $\begin{array}{l}0.953 \\
(0.042)\end{array}$ \\
\hline$p_{12}$ & & & & $\begin{array}{l}0.000 \\
(0.000)\end{array}$ & $\begin{array}{l}0.000 \\
(0.000)\end{array}$ \\
\hline$p_{21}$ & & & & $\begin{array}{l}0.038 \\
(0.031)\end{array}$ & $\begin{array}{l}0.042 \\
(0.036)\end{array}$ \\
\hline$p_{22}$ & & $\begin{array}{l}0.993 \\
(0.008)\end{array}$ & $\begin{array}{l}0.976 \\
(0.014)\end{array}$ & $\begin{array}{l}0.962 \\
(0.031)\end{array}$ & $\begin{array}{l}0.958 \\
(0.036)\end{array}$ \\
\hline$p_{31}$ & & & & $\begin{array}{l}0.000 \\
(0.000)\end{array}$ & $\begin{array}{l}0.000 \\
(0.000)\end{array}$ \\
\hline$p_{32}$ & & & & $\begin{array}{l}0.028 \\
(0.022)\end{array}$ & $\begin{array}{l}0.031 \\
(0.023)\end{array}$ \\
\hline$\phi_{1}$ & $\begin{array}{l}0.443 \\
(0.038)\end{array}$ & $\begin{array}{l}0.472 \\
(0.086)\end{array}$ & $\begin{array}{l}0.531 \\
(0.079)\end{array}$ & $\begin{array}{l}0.539 \\
(0.084)\end{array}$ & $\begin{array}{l}0.518 \\
(0.082)\end{array}$ \\
\hline$\phi_{2}$ & $\begin{array}{l}0.044 \\
(0.039)\end{array}$ & $\begin{array}{l}0.022 \\
(0.086)\end{array}$ & $\begin{array}{l}-0.052 \\
(0.068)\end{array}$ & $\begin{array}{l}0.072 \\
(0.085)\end{array}$ & $\begin{array}{l}-0.062 \\
(0.092)\end{array}$ \\
\hline$\phi_{3}$ & $\begin{array}{l}0.201 \\
(0.043)\end{array}$ & & $\begin{array}{l}0.205 \\
(0.062)\end{array}$ & & $\begin{array}{l}0.207 \\
(0.084)\end{array}$ \\
\hline$\phi_{4}$ & $\begin{array}{l}0.178 \\
(0.045)\end{array}$ & & $\begin{array}{l}0.242 \\
(0.063)\end{array}$ & & $\begin{array}{l}0.051 \\
(0.092)\end{array}$ \\
\hline$\sigma_{1}^{2}$ & $\begin{array}{l}10.98 \\
(1.25)\end{array}$ & $\begin{array}{l}15.80 \\
(2.48)\end{array}$ & $\begin{array}{l}3.55 \\
(0.49)\end{array}$ & $\begin{array}{l}26.68 \\
(5.74)\end{array}$ & $\begin{array}{l}28.09 \\
(6.84)\end{array}$ \\
\hline$\sigma_{2}^{2}$ & & $\begin{array}{l}4.55 \\
(0.85)\end{array}$ & $\begin{array}{l}36.53 \\
(10.63)\end{array}$ & $\begin{array}{l}1.50 \\
(0.43)\end{array}$ & $\begin{array}{l}1.38 \\
(0.45)\end{array}$ \\
\hline$\sigma_{3}^{2}$ & & & & $\begin{array}{l}4.24 \\
(0.86)\end{array}$ & $\begin{array}{l}4.06 \\
(0.82)\end{array}$ \\
\hline$\mu_{1}$ & $\begin{array}{l}0.302 \\
(0.263)\end{array}$ & $\begin{array}{l}-0.933 \\
(0.920)\end{array}$ & $\begin{array}{l}2.080 \\
(2.909)\end{array}$ & $\begin{array}{l}-0.546 \\
(1.632)\end{array}$ & $\begin{array}{l}0.228 \\
(1.407)\end{array}$ \\
\hline$\mu_{2}$ & & $\begin{array}{l}6.034 \\
(0.509)\end{array}$ & $\begin{array}{l}-4.494 \\
(3.444)\end{array}$ & $\begin{array}{l}0.559 \\
(0.837)\end{array}$ & $\begin{array}{l}1.326 \\
(0.691)\end{array}$ \\
\hline$\mu_{3}$ & & & & $\begin{array}{l}6.031 \\
(0.595)\end{array}$ & $\begin{array}{l}5.581 \\
(0.810)\end{array}$ \\
\hline$L$ & -405.66 & -400.25 & -370.72 & -377.90 & -367.95 \\
\hline$M$ & 69.88 & 59.94 & 5.48 & 19.89 & 75.42 \\
\hline$M_{c}$ & 10.95 & 5.99 & 10.95 & 5.99 & 15.75 \\
\hline
\end{tabular}


Table 4: Model estimates for Germany. The entries in the row labelled $M$ are, respectively: (col. 1) Likelihood ratio (LR) test of $n=1$ against $n=2$ conditional on $p=4$; (col. 2) LR test of $p=2$ against $p=4$ conditional on $n=2$; (col. 3) LR test of $n=2$ against $n=3$ conditional on $p=4$; (col. 4) LR test of $p=2$ against $p=4$ conditional on $n=3$; (col. 5) LR test of $n=1$ against $n=3$ conditional on $p=4$. The entries in the row labelled $M_{c}$ are the corresponding $5 \%$ critical values.

\begin{tabular}{|c|c|c|c|c|c|}
\hline & $\begin{array}{l}n=1 \\
p=4\end{array}$ & $\begin{array}{l}n=2 \\
p=2\end{array}$ & $\begin{array}{l}n=2 \\
p=4\end{array}$ & $\begin{array}{l}n=3 \\
p=2\end{array}$ & $\begin{array}{l}n=3 \\
p=4\end{array}$ \\
\hline$p_{11}$ & & $\begin{array}{l}0.911 \\
(0.047)\end{array}$ & $\begin{array}{l}0.852 \\
(0.117)\end{array}$ & $\begin{array}{l}0.875 \\
(0.053)\end{array}$ & $\begin{array}{l}0.710 \\
(0.157)\end{array}$ \\
\hline$p_{12}$ & & & & $\begin{array}{l}0.000 \\
(0.000)\end{array}$ & $\begin{array}{l}0.000 \\
(0.000)\end{array}$ \\
\hline$p_{21}$ & & & & $\begin{array}{l}0.285 \\
(0.134)\end{array}$ & $\begin{array}{l}0.186 \\
(0.073)\end{array}$ \\
\hline$p_{22}$ & & $\begin{array}{l}0.908 \\
(0.047)\end{array}$ & $\begin{array}{l}0.932 \\
(0.037)\end{array}$ & $\begin{array}{l}0.715 \\
(0.134)\end{array}$ & $\begin{array}{l}0.814 \\
(0.073)\end{array}$ \\
\hline$p_{31}$ & & & & $\begin{array}{l}0.000 \\
(0.000)\end{array}$ & $\begin{array}{l}0.000 \\
(0.000)\end{array}$ \\
\hline$p_{32}$ & & & & $\begin{array}{l}0.105 \\
(0.962)\end{array}$ & $\begin{array}{l}0.155 \\
(0.075)\end{array}$ \\
\hline$\phi_{1}$ & $\begin{array}{l}0.343 \\
(0.046)\end{array}$ & $\begin{array}{l}0.163 \\
(0.097)\end{array}$ & $\begin{array}{l}0.262 \\
(0.086)\end{array}$ & $\begin{array}{l}0.088 \\
(0.094)\end{array}$ & $\begin{array}{l}0.200 \\
(0.055)\end{array}$ \\
\hline$\phi_{2}$ & $\begin{array}{l}-0.087 \\
(0.043)\end{array}$ & $\begin{array}{l}-0.230 \\
(0.099)\end{array}$ & $\begin{array}{l}-0.067 \\
(0.082)\end{array}$ & $\begin{array}{l}-0.300 \\
(0.096)\end{array}$ & $\begin{array}{l}-0.057 \\
(0.073)\end{array}$ \\
\hline$\phi_{3}$ & $\begin{array}{l}0.062 \\
(0.045)\end{array}$ & & $\begin{array}{l}0.051 \\
(0.083)\end{array}$ & & $\begin{array}{l}-0.066 \\
(0.059)\end{array}$ \\
\hline$\phi_{4}$ & $\begin{array}{l}0.274 \\
(0.052)\end{array}$ & & $\begin{array}{l}0.427 \\
(0.085)\end{array}$ & & $\begin{array}{l}0.572 \\
(0.056)\end{array}$ \\
\hline$\sigma_{1}^{2}$ & $\begin{array}{l}5.77 \\
(0.69)\end{array}$ & $\begin{array}{l}3.67 \\
(0.73)\end{array}$ & $\begin{array}{l}3.05 \\
(0.79)\end{array}$ & $\begin{array}{l}3.38 \\
(0.78)\end{array}$ & $\begin{array}{l}4.19 \\
(1.50)\end{array}$ \\
\hline$\sigma_{2}^{2}$ & & $\begin{array}{l}5.37 \\
(1.06)\end{array}$ & $\begin{array}{l}8.44 \\
(2.37)\end{array}$ & $\begin{array}{l}1.27 \\
(0.66)\end{array}$ & $\begin{array}{l}0.63 \\
(0.18)\end{array}$ \\
\hline$\sigma_{3}^{2}$ & & & & $\begin{array}{l}5.62 \\
(1.07)\end{array}$ & $\begin{array}{l}8.06 \\
(1.68)\end{array}$ \\
\hline$\mu_{1}$ & $\begin{array}{l}1.281 \\
(0.192)\end{array}$ & $\begin{array}{l}1.400 \\
(0.326)\end{array}$ & $\begin{array}{l}2.286 \\
(0.610)\end{array}$ & $\begin{array}{l}0.962 \\
(0.335)\end{array}$ & $\begin{array}{l}0.773 \\
(0.770)\end{array}$ \\
\hline$\mu_{2}$ & & $\begin{array}{l}4.563 \\
(0.425)\end{array}$ & $\begin{array}{l}4.996 \\
(1.167)\end{array}$ & $\begin{array}{l}2.941 \\
(0.360)\end{array}$ & $\begin{array}{l}2.385 \\
(0.437)\end{array}$ \\
\hline$\mu_{3}$ & & & & $\begin{array}{l}4.745 \\
(0.362)\end{array}$ & $\begin{array}{l}3.998 \\
(0.665)\end{array}$ \\
\hline$L$ & -323.67 & -330.72 & -317.30 & -326.65 & -309.39 \\
\hline$M$ & 12.74 & 26.83 & 15.82 & 34.52 & 28.57 \\
\hline$M_{c}$ & 10.95 & 5.99 & 10.95 & 5.99 & 15.75 \\
\hline
\end{tabular}



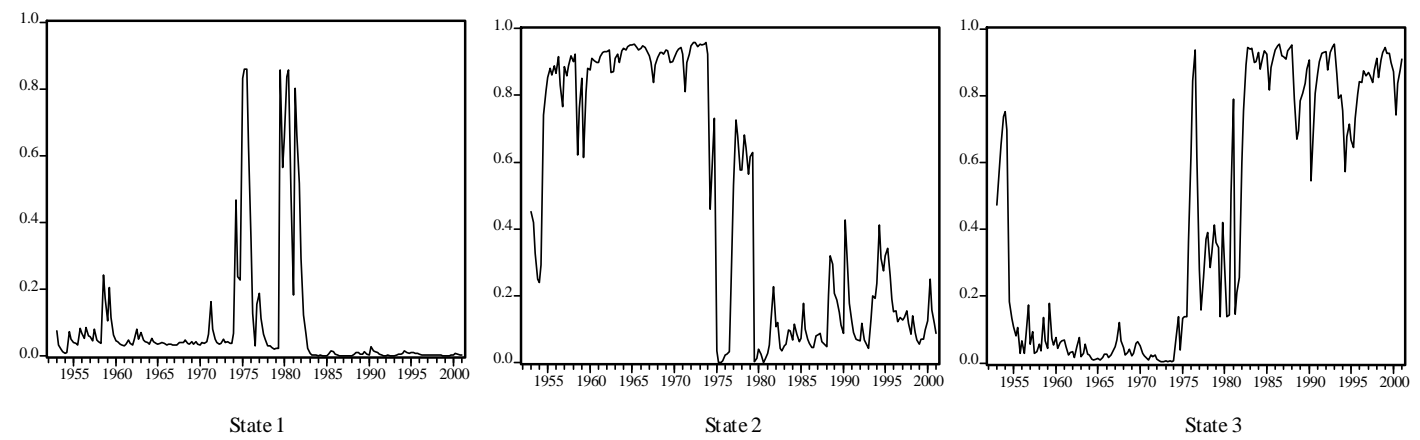

(a) U.K.
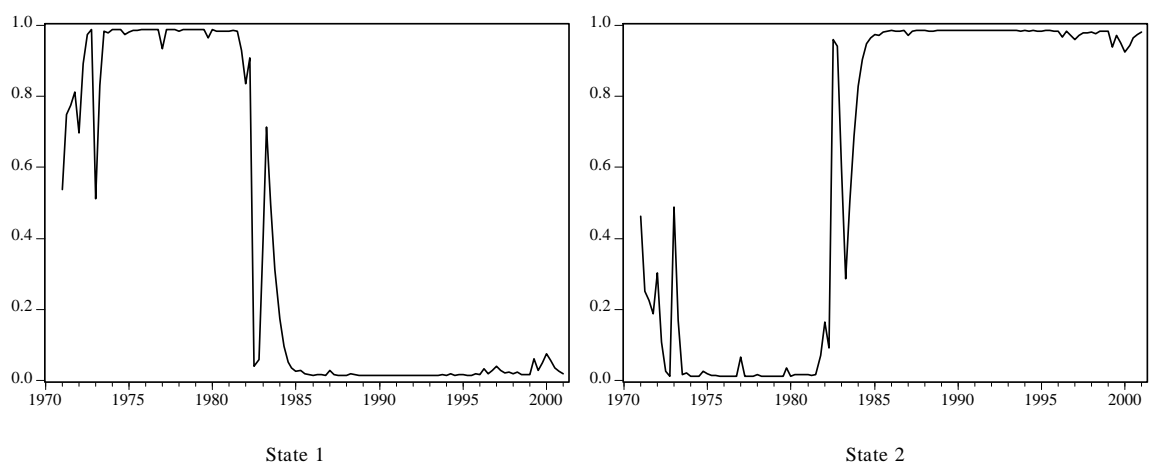

(b) France
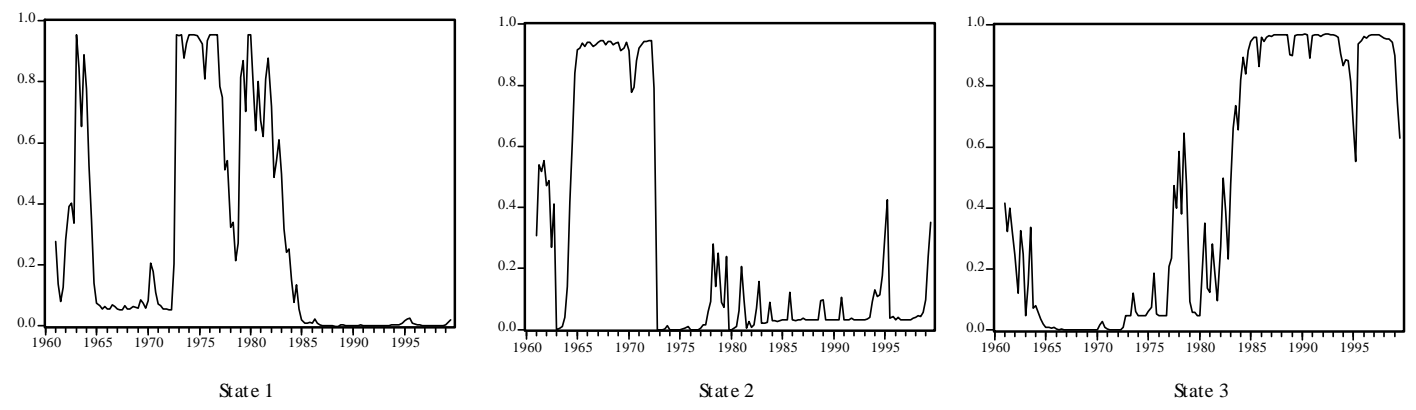

(c) Italy
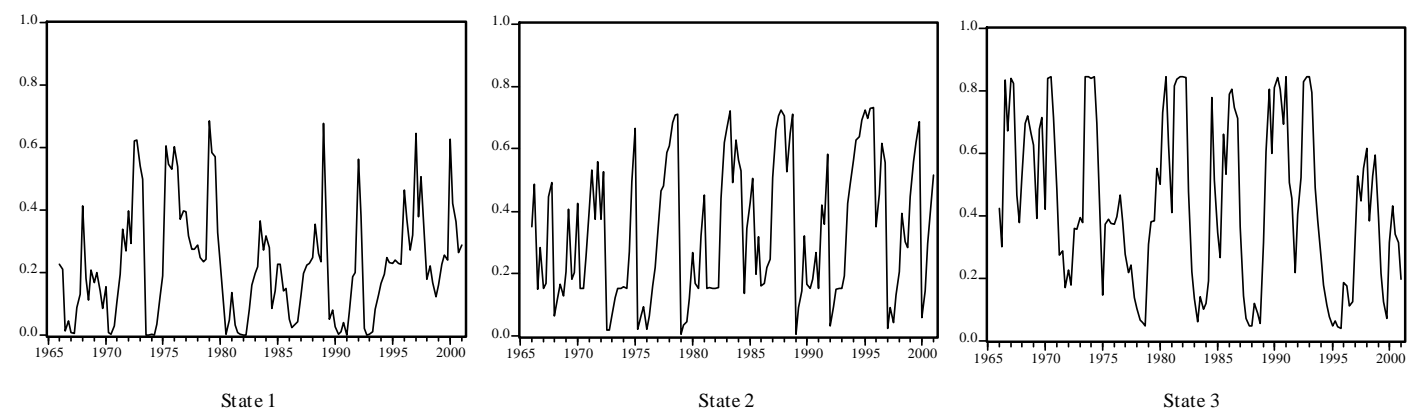

(d) Germany

Figure 1. Filtered state probabilities 


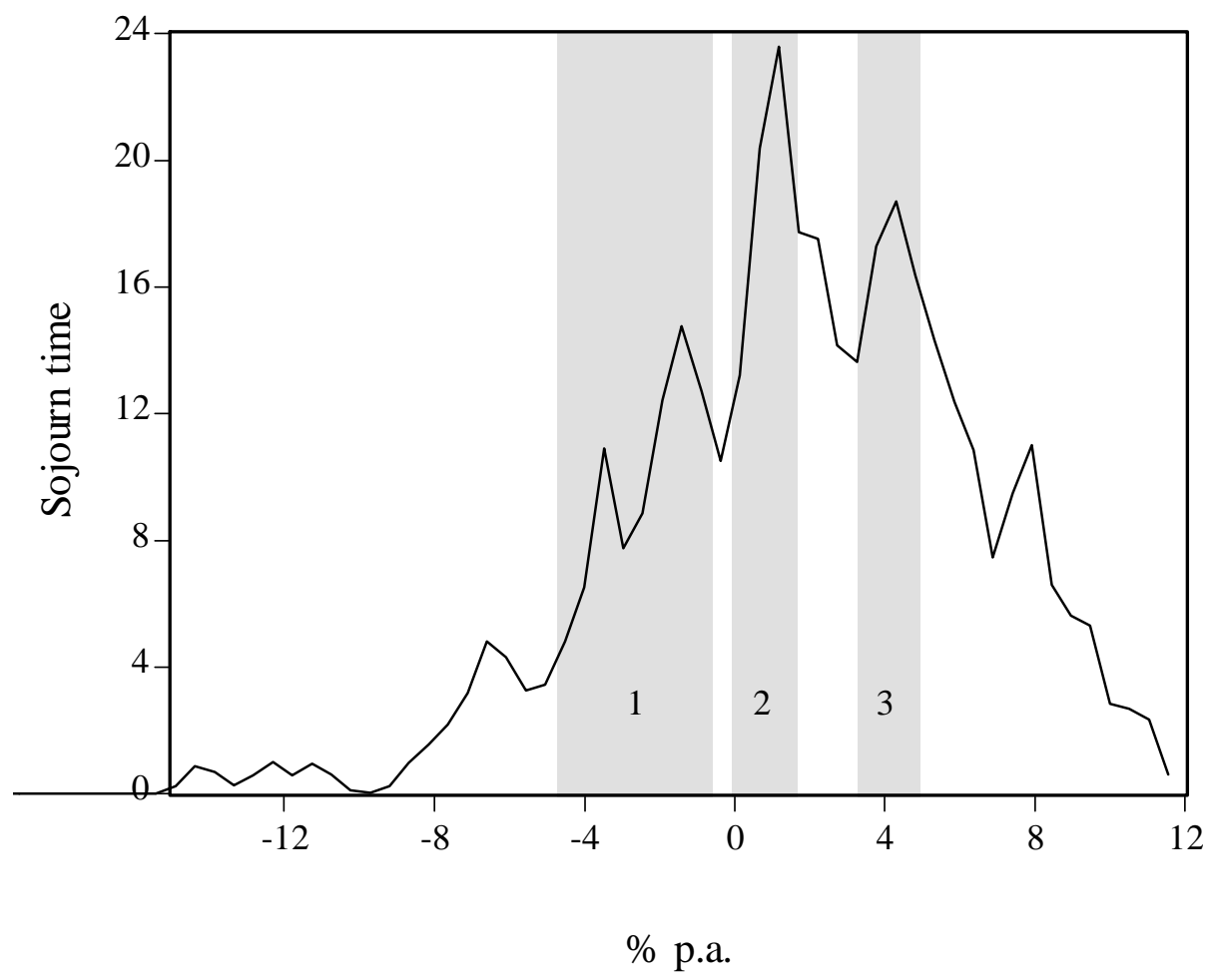

(a) U.K.

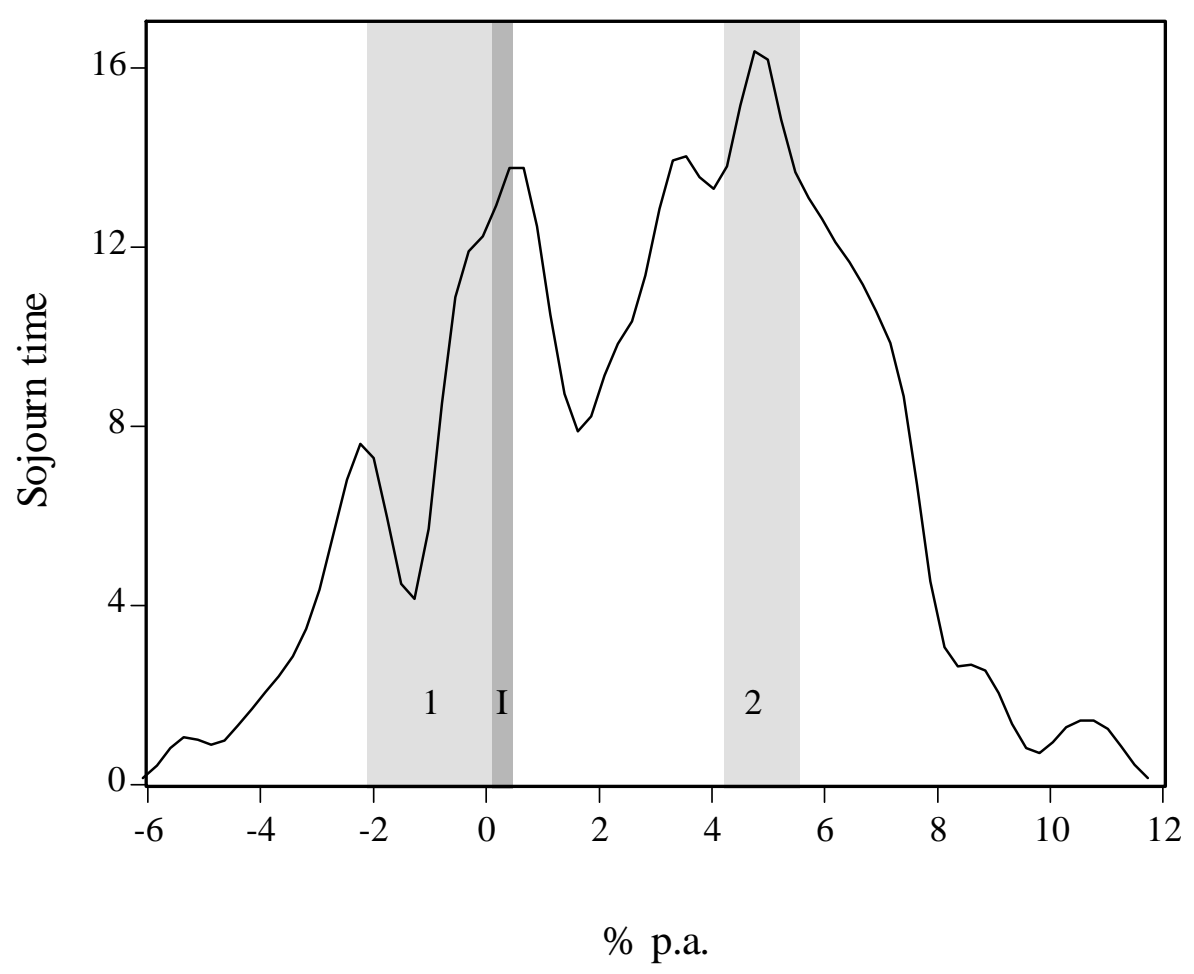

(b) France 


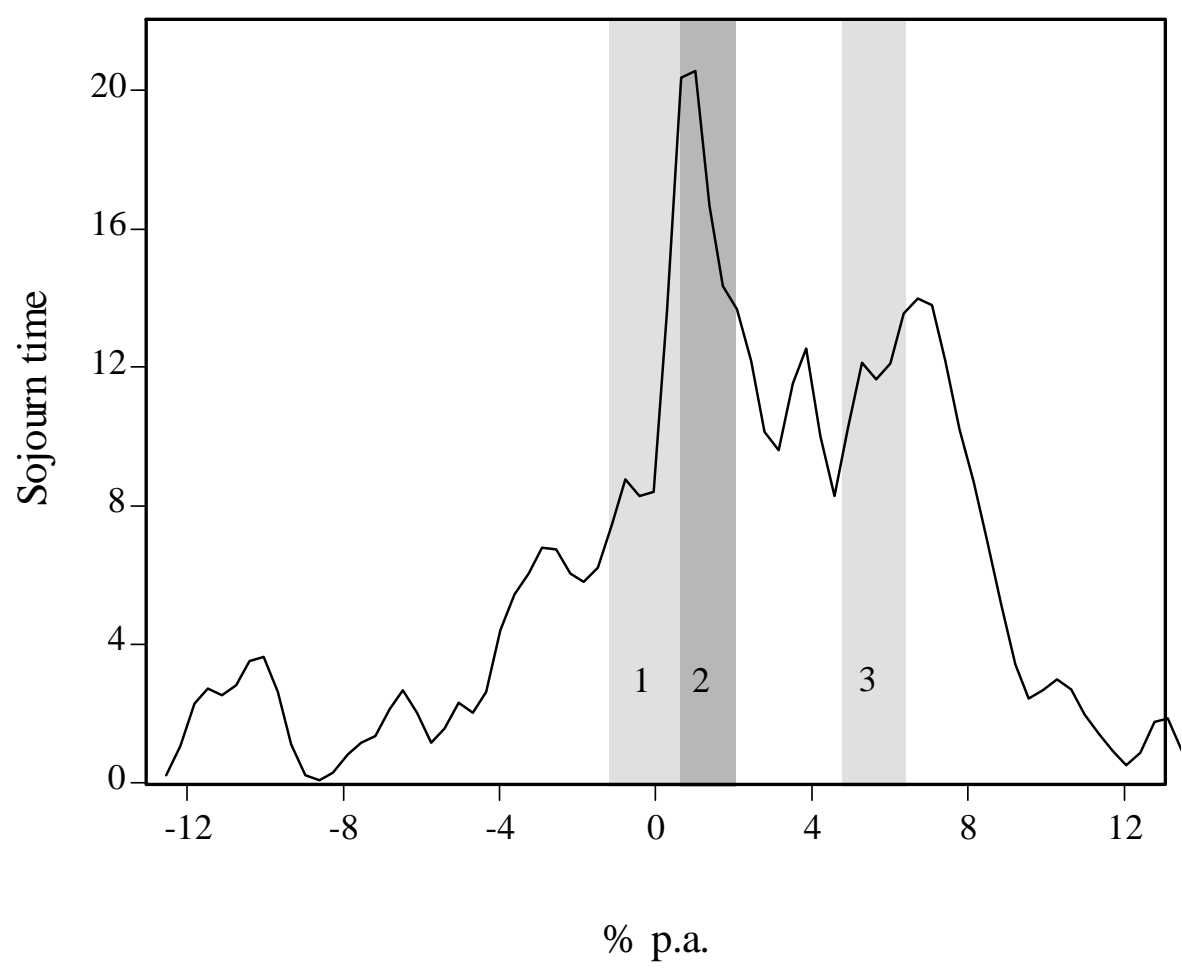

(c) Italy

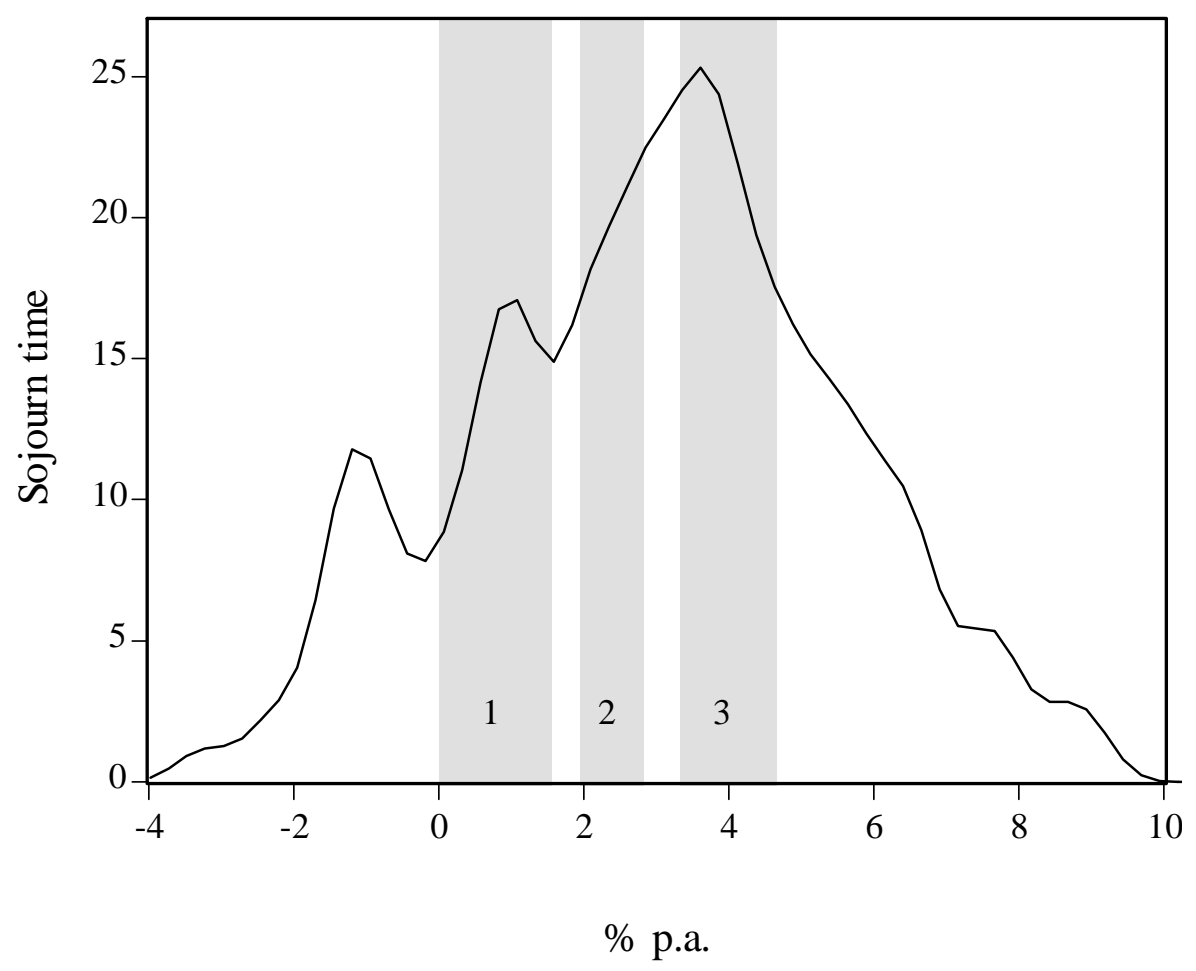

(d) Germany

Figure 2. Spatial densities. The shaded areas represent one standard error bands around the estimated state means from Tables 1 to 4 . Labels denote states. The darker area in (b), labelled I, is the single state from the $p=1$ model for France. States 1 and 2 in (c) overlap in the interval 0.64 to 1.64: the latter state is shaded darker for convenience. 


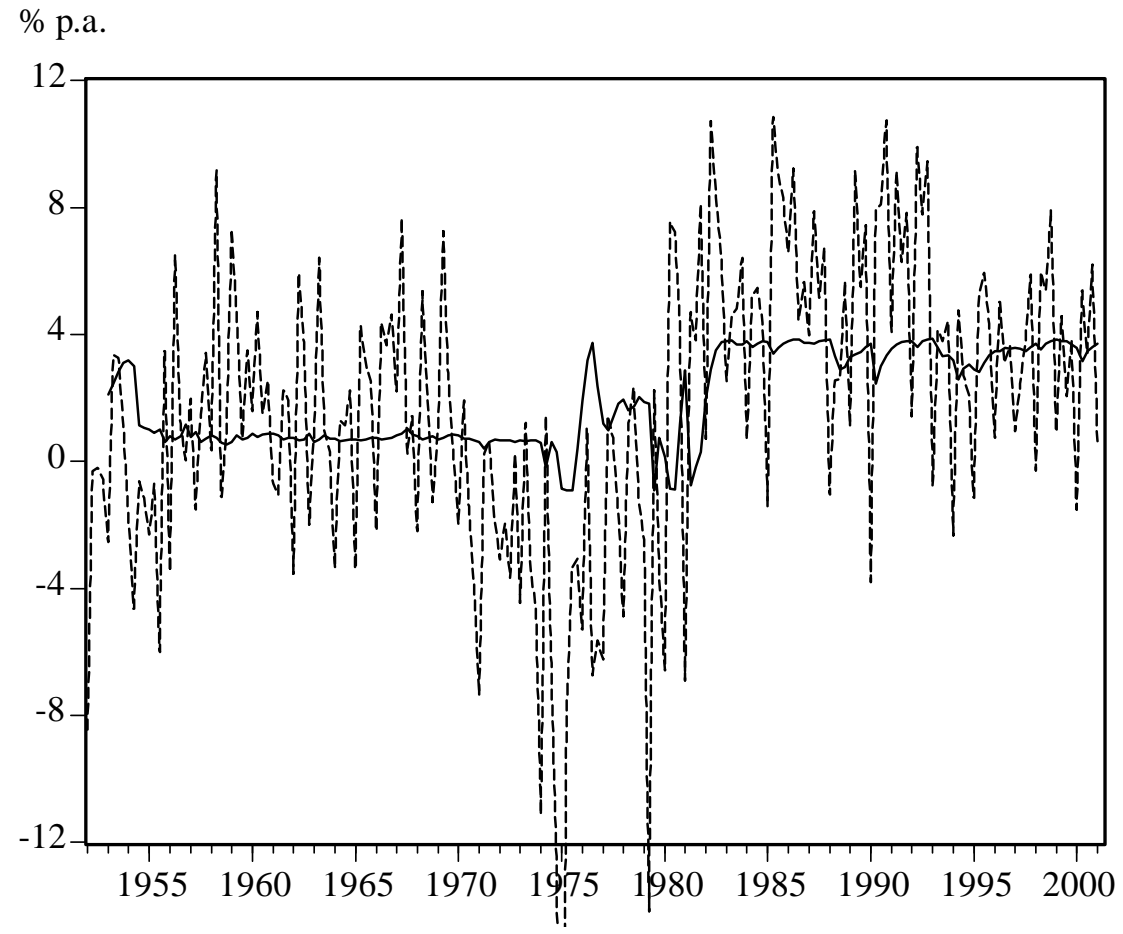

(a) U.K.

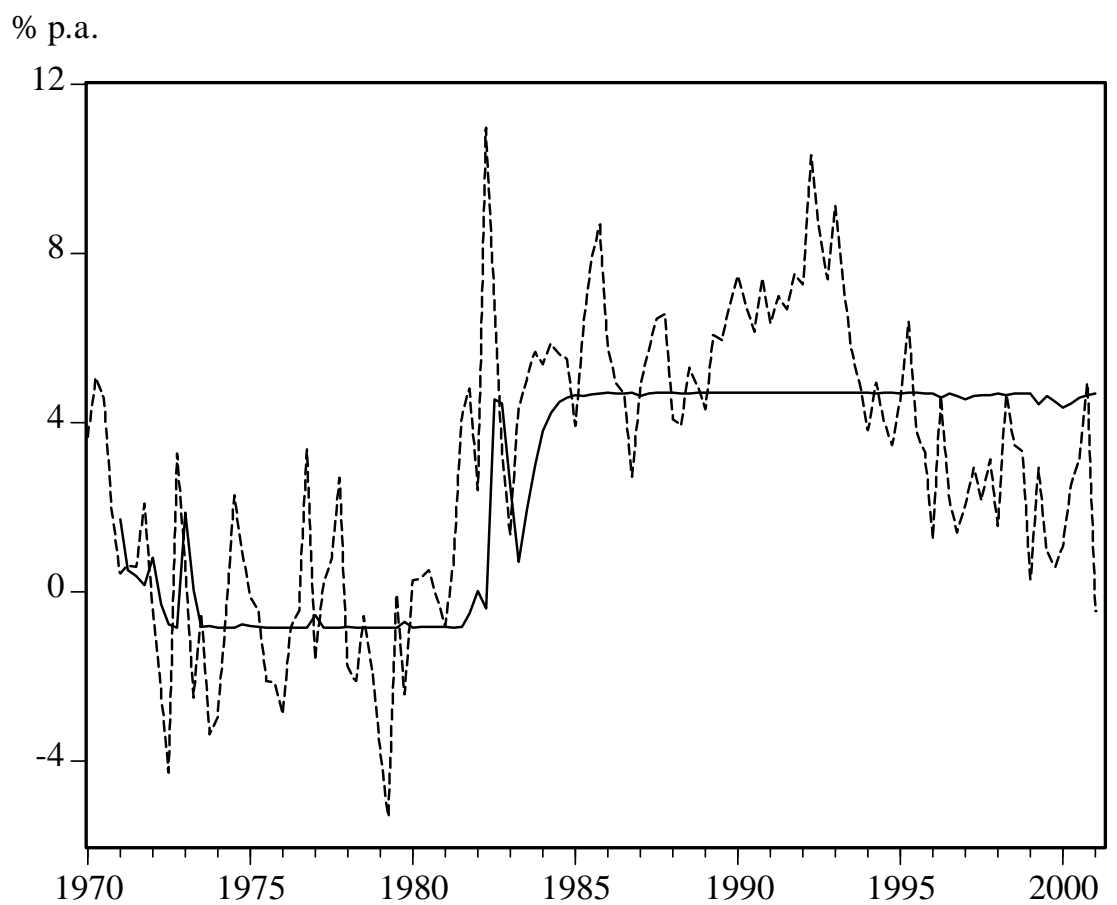

(b) France 
$\%$ p.a.

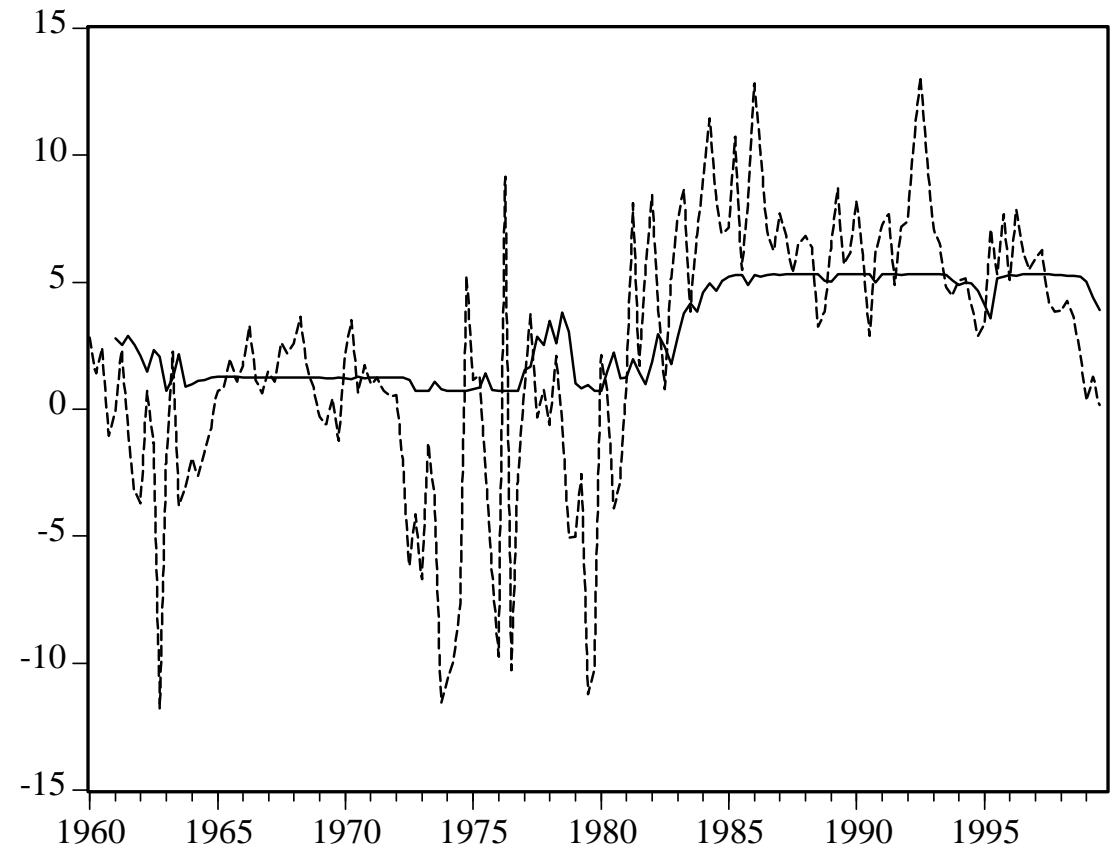

(c) Italy

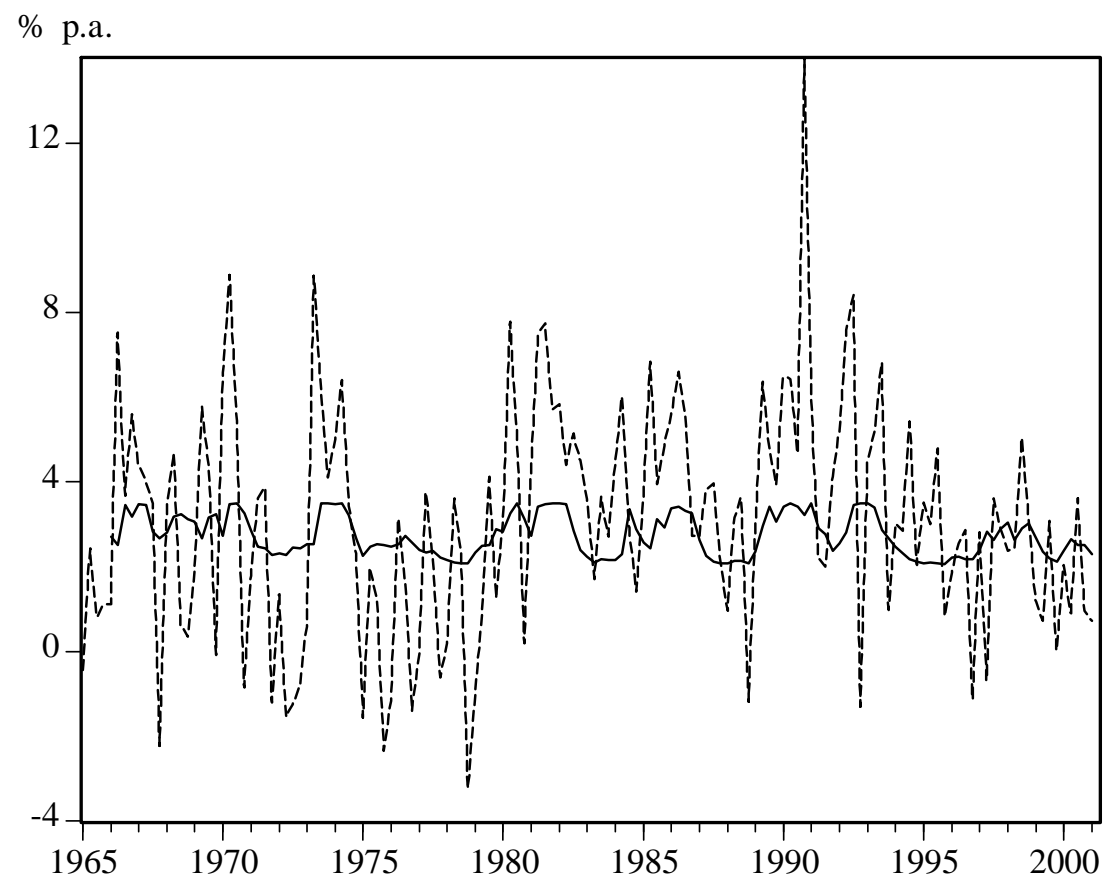

(d) Germany

Figure 3. Ex-ante (solid line) and ex-post (dashed line) real interest rates. 